\title{
Magic and Disbelief in Carolingian Lyon
}

\author{
Michael D. Bailey ${ }^{1}$
}

Doubt, disbelief, and skepticism have become important topics in the study of medieval Europe. Following a seminal article by the historian Susan Reynolds, medievalists from many disciplines have examined a range of tendencies often grouped together under the unlovely but encompassing term "unbelief." 2 They are engaged in an important project. In the overall historiography of Europe and the West, skeptical inquiry founded on the rejection of any kind of unquestioning belief has long stood as a hallmark of modernity, set against an enduring stereotype of the Middle Ages as credulous, superstitious, and altogether irrational. ${ }^{3}$ A significant level of sophistication in dealing with intellectual or epistemological uncertainty is often thought to have

${ }^{1}$ Iowa State University, USA.

Portions of this essay were presented at a seminar at King's College, Cambridge, in June 2019. I thank John Arnold and Miri Rubin for organizing the seminar and hosting me, and all the participants for their valuable feedback. Additional thanks to John Arnold, who later very helpfully commented on the full essay.

2 Susan Reynolds, "Social Mentalities and the Cases of Medieval Scepticism," Transactions of the Royal Historical Society, 6th series, vol. 1 (1991): 21-41. For an objection to the term "unbelief," see Dorothea Weltecke, "Beyond Religion: On the Lack of Belief during the Central and Later Middle Ages," in Religion and Its Other: Secular and Sacral Concepts and Practices in Interaction, ed. Heike Bock, Jörg Fuechter, and Michi Knecht (Frankfurt: Campus, 2009), 101-14. Weltecke, "Der Narr spricht: Es ist kein Got": Atheismus, Unglauben und Glaubenszweifel vom 12. Jabrhundert bis zur Neuzeit (Frankfurt: Campus, 2010), also discusses terminology at various points, esp. 257-95.

${ }^{3}$ Reynolds, "Social Mentalities," 22; John H. Arnold, Belief und Unbelief in Medieval Europe (London: Hodder Arnold, 2005), 4; Sabina Flanagan, Doubt in an Age of Faith: Uncertainty in the Long Twelfth Century (Turnhout: Brepols, 2008), 1; Peter Dinzelbacher, Unglaube im "Zeitalter des Glaubens": Atheismus und Skeptizismus im Mittelalter (Badenweiler: Bachmann, 2009), 1-2; Frances Andrews, "Introduction," in Doubting Christianity: The Church and Doubt, ed. Frances Andrews, Charlotte Metheun, and Andrew Spicer, Studies in Church History 52 (Cambridge: Cambridge University Press, 2016), 1-16, at 3. Studies of unbelief in antiquity also take this point as their frame: see Tim Whitmarsh, Battling the Gods: Atheism in the Ancient World (New York: Knopf, 2015), 4-5. 
emerged only in the early modern period, if not later. ${ }^{4}$ Such notions remain a prime example of how, in the words of one expert, almost no other periodization in history carries so much consequence as the divide between the "medieval" and the "modern," largely because that division functions "less as a historical marker than as a massive value judgment." 5

Thus far, skepticism or outright disbelief in magic have played only a small role in the emerging scholarship on medieval unbelief. John Arnold gives some space to magical practices in his expansive treatment of Belief and Unbelief in Medieval Europe, for example, and Matteo Duni has examined late medieval skepticism about witchcraft in his contribution to a recent collection on religious doubt. ${ }^{6}$ Magical practices could engender manifold uncertainties, however, ranging from whether they were real or illusory in their effects, to whether their power might be natural or demonic, leading ultimately to the question of whether they were potentially tolerable or invariably illicit. The very terminology surrounding magic is often slippery and elusive, creating problems for both medieval authorities and modern scholars. ${ }^{7}$

That these profound dilemmas have yet to be fully integrated into the study of unbelief in the Middle Ages is perhaps not surprising given that, aside from the matter of legal and intellectual condemnation, studies of medieval magic themselves often skirt questions of essential

${ }^{4}$ Dallas G. Denery II, "Uncertainty and Deception in the Medieval and Early Modern Court," in Uncertain Knowledge: Scepticism, Relativism, and Doubt in the Middle Ages, ed. Dallas G. Denery II, Kantik Gosh, and Nicolette Zeeman (Turnhout: Brepols, 2014), 13-36, at 15-18.

5 Margreta de Grazia, "The Modern Divide: From Either Side," Journal of Medieval and Early Modern Studies 37 (2007): 453-67, at 453; see also Kathleen Davis, Periodization and Sovereignty: How Ideas of Feudalism and Secularization Govern the Politics of Time (Philadelphia: University of Pennsylvania Press, 2008), 5-6.

6 Arnold, Belief and Unbelief, 96-99; Duni, "Doubting Witchcraft: Theology, Jurists, Inquisitors during the Fifteenth and Sixteenth Centuries," in Doubting Christianity, 20331. Other examples include Paolo Golinelli, Il Medioevo degli increduli: Miscredenti, beffatori, anticlericali (Milan: Mursia, 2009), esp. 29-43; while Carol Lansing treats magical fraud in her essay "Popular Belief and Heresy," in A Companion to the Medieval World, ed. Carol Lansing and Edward D. English (Chichester: Wiley-Blackwell, 2009), 276-92.

7 This issue is confronted directly by Richard Kieckhefer, "Rethinking How to Define Magic," in The Routledge History of Medieval Magic, ed. Sophie Page and Catherine Rider (London: Routledge, 2019), 15-25; Claire Fanger, "For Magic: Against Method," ibid., 26-36; Bernd-Christian Otto, "A Discourse Historical Approach Towards Medieval Learned Magic," ibid., 37-47; and David L. d'Avray, "The Concept of Magic," ibid., 48-56. 
credulity or skepticism. ${ }^{8}$ Yet such questions are essential. Disbelief in magic - that is, the putative rejection of magical beliefs and practices as matters of serious intellectual concern - has played an enormous role in establishing the fraught divide between the medieval and the modern to which I have already alluded. The very scope of the issue, though, has led to a certain degree of scholarly fatigue.

To put the matter curtly, scholars of magic have long since grown disenchanted with Max Weber's notion of the disenchantment of the world (Entzauberung der Welt). In fairness, Weber himself was never entirely enamored with this concept, and he never developed it at length. ${ }^{9}$ That left subsequent scholars an evocative but loosely defined term with which to play. Despite the fact that Europe's major witch hunts were a decidedly early modern phenomenon afflicting both Catholic and Protestant lands, many continued to associate disenchantment primarily with the Reformation, as Weber seemed to have indicated, until R. W. Scribner effectively undermined that relationship. ${ }^{10}$ Others placed the moment of disenchantment in the Scientific Revolution or Enlightenment, although the fit was never perfect in any epoch. Some medievalists also joined the fray, arguing in the opposite chronological direction that many medieval thinkers were often quite rational, and in that sense disenchanted, in their approach to magic. ${ }^{11}$ Most recently, scholars of modern magic have questioned

8 In contrast, on skepticism associated with witchcraft, mainly in the early modern period, see Walter Stephens, "The Sceptical Tradition," in The Oxford Handbook of Witchcraft in Early Modern Europe and Colonial America, ed. Brian P. Levack (Oxford: Oxford University Press, 2013), 101-21. Stephens's important earlier study, Demon Lovers: Witchcraft, Sex, and the Crisis of Belief (Chicago: University of Chicago Press, 2002), situated late medieval witchcraft at the center of major epistemological debates.

9 Gilbert G. Germain, A Discourse on Disenchantment: Reflections on Politics and Technology (Albany: State University of New York Press, 1993), 28.

10 R. W. Scribner, "The Reformation, Popular Magic, and the 'Disenchantment of the World," Journal of Interdisciplinary History 23 (1992-93): 475-94; also Scribner, "Magic and the Formation of Protestant Popular Culture in Germany," in R. W. Scribner, Religion and Culture in Germany (1400-1800), ed. Lyndal Roper, Studies in Medieval and Reformation Thought 81 (Leiden: Brill, 2001), 323-45. A classic, highly nuanced account of the Reformation's effect on magic remains Keith Thomas, Religion and the Decline of Magic (New York: Scribner's, 1971).

11 Richard Kieckhefer, "The Specific Rationality of Medieval Magic," American Historical Review 99 (1994): 813-36; Michael D. Bailey, "The Disenchantment of Magic: Spells, Charms, and Superstition in Early European Witchcraft Literature," American Historical Review 111 (2006): 383-404. 
whether Western modernity itself can truly be categorized as disenchanted in any meaningful way. ${ }^{12}$

Another reason why doubts about magic may not thus far have figured more prominently in the study of unbelief overall is that many of the scholars who have focused on different forms of medieval unbelief have tended to begin their investigations in the twelfth century, and they have often privileged the later medieval period over the earlier. ${ }^{13}$ This is due mainly to the impact of the intellectual revival still characterized as the "renaissance of the twelfth century," which led to a flowering of disputation and hence of doubt, at least of the academic variety, on many issues. It is also likely due to the far greater number of sources available from the later medieval period compared to the earlier, which allows for greater insight into an array of issues. Collectively, although no doubt unintentionally, this de facto later medieval focus can appear to reinforce a teleology in which doubt and disbelief, as markers of intellectual sophistication, grew progressively as European society moved forward through time, from late medieval toward early modern. Belief in magic, however, followed a different track.

Of course, the term "belief' is itself fluid and uncertain, and it can designate various kinds of conviction, credulity, or understanding. ${ }^{14}$ Nevertheless, as a generality we may assert that most later medieval authorities - religious, judicial, and intellectual - tended to be more credulous, and hence more concerned, about magic than earlier authorities had been. More precisely, they grew more certain of the real efficacy of demonic magic within the physical world. ${ }^{15}$ One factor

\footnotetext{
12 Michael Saler, "Modernity and Enchantment: A Historiographic Review," American Historical Review 111 (2006): 692-716; Egil Asprem, The Problem of Disenchantment: Scientific Naturalism and Esoteric Discourse, 1900-1939 (Leiden: Brill, 2014); Jason A. JosephsonStorm, The Myth of Disenchantment: Magic, Modernity, and the Birth of the Human Sciences (Chicago: University of Chicago Press, 2017). I approached the question from a medieval perspective in the final chapter of Michael D. Bailey, Fearful Spirits, Reasoned Follies: The Boundaries of Superstition in Late Medieval Europe (Ithaca, N.Y.: Cornell University Press, 2013), 242-50.

13 Jinty Nelson, "Carolingian Doubt?" in Doubting Christianity, 65-86, at 66.

14 On belief's historical valences, see Ethan S. Shagan, The Birth of Modern Belief: Faith and Judgment from the Middle Ages to the Enlightenment (Princeton, N.J.: Princeton University Press, 2018).

15 Michael D. Bailey, "Diabolic Magic," in The Cambridge History of Magic and Witchcraft in the West: From Antiquity to the Present, ed. David J. Collins (Cambridge: Cambridge
} 
underlying this development was the influx of erudite magical texts from the Muslim world, which was itself part of Western Europe's intellectual revival starting around the twelfth century. ${ }^{16}$ By the late thirteenth or early fourteenth century, demonology had reemerged as a serious intellectual topic for the first time since the patristic era. ${ }^{17} \mathrm{By}$ the fifteenth century, witch trials had begun to appear. This is not a trajectory that fits comfortably with most general approaches to the study of unbelief in the Middle Ages that have emerged so far.

I lay out these points in order to establish the larger context for the focused analysis that I will develop here, but I will not, in fact, directly address such grand historical trajectories. To return for a moment to a Weberian frame, in a penetrating essay published in 2008, Alexandra Walsham argued that scholars should abandon the effort to situate disenchantment in any single age or epoch. Even more importantly, she stressed that we should not imagine that skepticism or disbelief grew progressively over time, advancing along a clearly "linear path of development." Instead, we should think "in terms of cycles of desacralization and resacralization, disenchantment and reenchantment," that would wax and wane over time. ${ }^{18}$ Within that framework, the imperative then becomes to understand how those cycles operated, and to do that, I would contend, we need to unpack the doubts and disbelief of particular historical moments, in order to understand how they functioned in their own terms rather than as part of any sweeping teleology. ${ }^{19}$

University Press, 2015), 361-92, at 361-62. Although as David J. Collins stresses in his "Scholasticism and High Medieval Opposition to Magic," in The Routledge History of Medieval Magic, ed. Sophie Page and Catherine Rider (London: Routledge, 2019), 461-74, there was no "unanimity in opinion or approach" to magic among scholastic thinkers (p. 461), and he effectively contrasts Thomas Aquinas's demonic concerns to Albertus Magnus's "more expansively accepting view" (pp. 467-69).

16 Bailey, "Diabolic Magic," 363; Collins, "Scholasticism and High Medieval Opposition," 462-63; Richard Kieckhefer, Magic in the Middle Ages (Cambridge: Cambridge University Press, 1989), 117-19.

17 Alain Boureau, Satan the Heretic: The Birth of Demonology in the Medieval West, trans. Teresa Lavender Fagan (Chicago: University of Chicago Press, 2006), 8-9.

18 Alexandra Walsham, "The Reformation and 'The Disenchantment of the World' Reassessed," The Historical Journal 51 (2008): 497-528, quote at 527.

19 Although I would also agree with Walsham ("The Reformation and "The Disenchantment of the World," 528) that such precision should not "eclipse the fact of long-term change." 
My analysis here, therefore, takes the form of a case study. I will focus on the Carolingian archbishop Agobard of Lyon's powerful statement of disbelief in a form of weather magic that was widely practiced, so he claimed, around that city in the early ninth century. As we will see, while his disbelief was unequivocal, it was not allencompassing. He did not reject the possibility of all kinds of magic, only certain practices that he sought to criticize. One aspect of my argument is that the manner in which Agobard structured and defended his disbelief can help us decipher how he came to hold the particular form of disbelief that he did. More broadly, I also want to show how disbelief does not always function as a simple antithesis to belief. Rather, these two seeming opposites could interact with and "implicate" each another in complex ways. ${ }^{20}$ Ultimately, it makes little sense to ask whether medieval people believed in magic or not. We should seek instead to understand the nature of both their belief and disbelief, what it entailed, and why.

\section{Magical beliefs around Lyon}

Compared to late medieval concerns, responses to magical practices in the early Middle Ages often seem admirably restrained and relatively skeptical. It is true that many early medieval law codes imposed harsh penalties particularly on magic used to cause harm, and this continued throughout the Carolingian period. ${ }^{21}$ Nevertheless, scholars have tended to emphasize the elements of doubt or disbelief expressed in various sources. Early medieval penitential literature, for example, frequently imposed penances not only for performing or participating in certain kinds of magical practices, but also for foolishly believing that they might be effective. ${ }^{22}$ Legal rulings, too, despite their potential

20 See Mathijs Pelkmans, "Outline for an Ethnography of Doubt," in Ethnographies of Doubt: Faith and Uncertainty in Contemporary Societies, ed. Mathijs Pelkmans (London: I. B. Taurus, 2013), 1-42, at 2.

21 E.g. a Carolingian code of 802: Alfred Boretius, ed., Capitularia regnum Francorum, Monumenta Germaniae Historica Leges 2 (Hanover: Hahn, 1883), 96.

22 This is especially evident in the nineteenth book of Burchard of Worm's Decretum, known as his Corrector, see Burchard, Decretorum libri viginti, Patrologia Latina 140 (Paris, 1880), cols. 537-1058; also John T. McNeill and Helena M. Gamer, eds., Medieval Handbooks of Penance: A Translation of the Principal Libri Poenitentiales (New York: Columbia University Press, 1938), 321-45. 
severity, often targeted incorrect or improper beliefs among the laity rather than the performance of magic per se. For example, a Carolingian capitulary from 785 seems to have been more intent on combatting residual paganism than on suppressing harmful magical rites when it condemned to death anyone who believed that a person could be a witch (striga) "after the manner of the pagans." 23 Such doubts were evident in church law as well. Perhaps most famously, the early tenth-century canon Episcopi concluded that women who believed themselves to travel at night in the train of the goddess Diana were in fact only deluded by demons. ${ }^{24}$

This skeptical declaration was enormously influential, continuing to shape church authorities' reaction to claims of witches flying through the night for the rest of the Middle Ages and beyond.25 Often overlooked, however, is that the canon's disbelief did not extend at all to the "pernicious art of sorcery and harmful magic" in general. The text as it stands appears to have fully accepted that such practices were real, and it enjoined bishops and their officials to "eradicate" them from their diocese. ${ }^{26}$ Like the canon Episcopi, Agobard of Lyon's tract De grandine et tonitruis (Concerning Hailstorms and Thunder) is now recognized as one of the major skeptical statements about magic from the early medieval period, ${ }^{27}$ and the good bishop himself is often

${ }_{23}$ Boretius, ed., Capitularia regnum Francorum, 68.

${ }^{24}$ For edition, see n. 25 below. For discussion, see Valerie I. J. Flint, The Rise of Magic in Early Medieval Europe (Princeton, N.J.: Princeton University Press, 1991), 122-26; Josef Steinruck, "Zauberei, Hexen- und Dämonenglaube im Sendhandbuch des Regino von Prüm," in Hexenglaube und Hexenprozesse im Raum Rhein-Mosel-Saar, ed. Gunther Franz and Franz Irsigler (Trier: Spee, 1995), 3-18; and Werner Tschacher, "Der Flug durch die Luft zwischen Illusionstheorie und Realitätsbeweis: Studien zum sog. Kanon Episcopi und zum Hexenflug," Zeitschrift der Savigny-Stiftung für Rechtsgeschichte 116, Kanonistische Abteilung 85 (1999), 225-76, which takes analysis up through the later medieval period.

25 For the fullest discussion of the canon's reception in the fifteenth century, see Martine Ostorero, Le diable au sabbat: Littérature démonologique et sorcellerie (1440-1460), Micrologus' Library 38 (Florence: SISMEL, 2011), 567-720.

${ }^{26}$ Joseph Hansen, ed., Quellen und Untersuchungen zur Geschichte des Hexenwahns und der Hexenverfolgung im Mittelalter (1901; reprint Hildesheim: Georg Olms, 1963), 38-39.

27 The title is not Agobard's. It derives from an addition to the sole known manuscript, Paris, Bibliothèque nationale de France, Lat. 2853, fols. 93r-106r: Item liber contra insulam unlgi opinionem de grandine et tonitruis. I follow the edition in Agobardi Lugdunensis opera omnia, ed. L. van Aker, Corpus Christianorum Continuatio Mediaevalis 52 (Turnhout: Brepols, 1981), 3-15 (hereafter DGT). A partial translation is found in Paul Edward 
credited as being almost modern in his rational and empirical approach. ${ }^{28}$ As with the canon, however, we will see that his disbelief was in fact carefully focused.

Information about Agobard's life, especially before he became archbishop, is sketchy and uncertain. According to the Annals of Lyon, he came from Spain (Hispania) to southern Gaul (Gallia Narbonensis) in 782. A decade later, he appears to have settled in Lyon. The Annals are not entirely trustworthy on all points, but at the very least, Agobard appears not to have been a Frank. Seemingly more certain is that he succeeded to the archbishopric of Lyon after the resignation of his predecessor, Leidrad, and he was confirmed in this office by a synod at Aachen in 816.29 Like Leidrad, Agobard was dedicated to ecclesiastical reform, and he was clearly concerned about the moral instruction and improvement of his flock. Seemingly toward this goal, he wrote $D e$ grandine et tonitruis sometime between 815 and 817, at the very outset of his episcopate. This short work appears to be of mixed genre. It most likely began as a sermon preached to a lay audience but then increasingly took on the nature of a learned treatise, emphasizing scriptural citation and meant most likely for other clergy to read. ${ }^{30}$

Agobard begins this tract with the sweeping declaration that "nearly everyone" in the region around Lyon, "nobles and commoners, citydwellers and country-folk, the old and the young, think that hail and thunder can be made at the will of human beings." This belief is entirely false, however, a position he asserts "without doubt." 31 In fact, he articulates a fairly complicated three-part belief structure. First, there are the people he labels tempestarii (storm-raisers) who supposedly

Dutton, ed., Carolingian Civilization: A Reader, 2nd ed. (Peterborough, Ont.: Broadview Press, 2004), 220-23. While I have consulted Dutton, translations here are my own.

28 See esp. Karl Heidecker, "Agobard en de onweermakers: Magie en rationaliteit in de vroege Middeleeuwen," in De betovering van het middeleeunse Christendom: Studies over ritueel en magie in de Middeleeuwen, ed. M. Mostert and A. Demyttenaere (Hilversum: Verloren, 1995), 171-94. Earlier examples include Allen Cabaniss, Agobard of Lyons: Churchman and Critic (Syracuse, N.Y.: Syracuse University Press, 1953), 25; and Egon Boshof, Erzbischof Agobard von Lyon: Leben und Werk (Cologne: Böhlau, 1969), 173.

${ }_{29}$ Boshof, Agobard von Lyon, 24-36.

30 Boshof, Agobard von Lyon, 170; Jean Jolivet, "Agobard de Lyon et les faiseurs de pluie," in La méthode critique au Moyen Age, ed. Mireille Chazan and Gilbert Dahan (Turnhout: Brepols, 2006), 15-25, at 25.

31 DGT 1, p. 3. 
employed incantations to summon violent storms to destroy crops. ${ }^{32}$ Then there are other practitioners who cannot raise storms but claim to be able to defend against them, for which they exact a payment from the local populace in the form of a regular tribute or tithe. ${ }^{33}$ Most strangely, he describes an entirely different sort of people who come from a land called Magonia, and who pilot ships through the air. Apparently without power to affect the weather themselves, these people pay the tempestarii for raising storms, and in turn they steal the crops damaged in those storms and transport them back to Magonia. ${ }^{34}$

Recent scholarship has tended to focus on the social context behind these contested beliefs. ${ }^{35}$ Paul Dutton, for example, has argued that they may represent a peasant strategy, or Agobard's encoding of such a strategy, to hide crops and resist both seigneurial taxes and ecclesiastical tithes. ${ }^{36}$ As for the beliefs themselves, he suggests that they were rooted in pagan weather rites and perhaps even the enduring worship of pagan weather deities. ${ }^{37}$ Others see no reason to posit active paganism in the heart of ninth-century Francia. Given how many ecclesiastical rites aimed at crop protection, Rob Meens has suggested that Agobard might have been engaged in a rhetoric targeting rival clerics. ${ }^{38}$ Probably the most likely explanation is more straightforward, that Agobard was challenging popular magical beliefs and perhaps even a set of

\footnotetext{
32 This term was in widespread use by Frankish writers at this time; for a list, see Heidecker, "Agobard en de onweermakers," 189-92; also Paul Edward Dutton, "Thunder and Hail over the Carolingian Countryside," in Dutton, Charlemagne's Mustache and Other Cultural Clusters of a Dark. Age (New York: Palgrave Macmillan, 2004), 169-88 and 264-72, at 172-74; Bernadette Filotas, Pagan Survivals, Superstitions and Popular Cultures in Early Medieval Pastoral Literature (Toronto: University of Toronto Press, 2005), 270-73.

33 DGT 15, p. 14.

34 DGT 2, p. 4. On possible meanings or derivations of this term, see Heidecker, "Agobard en de onweermakers," 179; Dutton, "Thunder and Hail," 174, 186; Filotas, Pagan Survivals 273-74.

35 Jolivet, "Agobard de Lyon," focuses on "methods of argumentation" but offers mainly summary with little analysis.

36 Dutton, “Thunder and Hail," 186.

${ }^{37}$ Dutton, "Thunder and Hail," 174; also Heidecker "Agobard en de onweermakers," 180.

38 Rob Meens, "Thunder over Lyon: Agobard, the tempestarii and Christianity," in Paganism in the Middle Ages: Threat and Fascination, ed. Carlos Steel, John Marenbon, and Werner Verbeke (Leuven: Leuven University Press, 2012), 157-66, at 164. See Heidecker, "Agobard en de onweermakers," 180-82, on ecclesiastical weather rites.
} 
"independent village sorcerers" who represented an obstacle to full ecclesiastical control over rural culture. ${ }^{39}$

What concerns me in this essay, however, is not so much what Agobard was opposing in his tract, or even why, but rather how he constructed that opposition. What arguments did he use to disrupt the supposedly near-universal belief in the weather magic of the tempestarii, what kinds of doubt did he bring into play, and what do these reveal about the ultimate nature of his own disbelief? The position he announces in his tract can be summarized easily enough: God controls the weather, human beings cannot. He intends to prove this mainly through scripture. There is another strand of argumentation woven through De grandine et tonitruis, however, in which Agobard draws on his own observation and investigation of the beliefs that he wants to challenge. Many scholars have noted this other line of argument, which has contributed greatly to Agobard's reputation as a deeply rational and for some an almost proto-modern thinker. ${ }^{40}$ Introducing modern notions of rationality or irrationality into discussions of medieval magic is rarely edifying, but there is no doubt that two very different kinds of skepticism and opposition to weather magic are evident here.

In the tract as we have it, arguments against the tempestarii drawn from Agobard's own experience appear only as relatively brief asides or digressions from his scriptural analysis. I will argue, however, that they actually represent the core of his disbelief. Others have noted how his text sits oddly between a popular sermon, in which one would expect colorful contemporary exempla, and a more learned treatise, built around systematic argumentation and the citation of past authorities. ${ }^{41}$ Obviously, the direction of the text's development would more likely have been from an earlier oral form toward a later literary one. I will pursue that insight, and the suggestion that the "traces of orality" remaining in the text represent its point of origin. ${ }^{42}$ Specifically regarding Agobard's adamant disbelief in the weather magic of the tempestarii, I will show how some of the scriptural citations that he marshalled to his cause could actually be read as supporting the idea of

39 Monica Blöcker, "Wetterzauber: Zu einem Glaubenskomplex des frühen Mittelalters," Francia 9 (1981): 117-31, at 125.

40 See n. 27 above.

41 Jolivet, "Agobard de Lyon"; followed by Meens, "Thunder Over Lyon."

42 Meens, "Thunder Over Lyon," 160; Boshof, Agobard von Lyon, 170. 
human control over weather via demonic magic, and indeed that they were read that way by many other medieval churchmen.

\section{Agobard's Scriptural critique}

The bulk of Agobard's scriptural arguments are drawn from two books of the Old Testament: Exodus and Job. From Exodus, his key example concerns Moses and Aaron's encounter with Pharaoh, and in particular their calling forth, through the power of God, of the seventh plague upon Egypt, that of hail. ${ }^{43}$ As Agobard relates, citing scripture, "Moses stretched forth his rod toward heaven, and the Lord sent thunder and hail and lightning running along the ground, and the Lord rained hail on the land of Egypt." He ends with his own comment, explicitly articulating the conclusion he wants to draw from this passage; namely, that it "shows the Lord alone as creator and author of the hail, not some human being." 44

Not everyone would interpret this passage in this way, however, as Agobard himself goes on to note. "Perhaps they who attribute this to human beings," he writes, "might say that Moses stretched forth his rod toward heaven, and therefore the storm was sent by a man." This objection actually plays into Agobard's hands. A standard position within medieval Christian discourse was that holy people might indeed appear to work wonders, but they never did so through their own power, only God's. Such reasoning lies at the root of Agobard's response. "Surely Moses was a good and just servant of the Lord," he writes, "but these would not dare claim that those whom they call tempestarii are good and just, but rather evil and unjust, and deserving of condemnation now and forever." Thus, the power of the tempestarii cannot be real, "for if, in imitation of Moses, these men were the authors of the hail, they would surely be servants of God, not servants of the devil." 45

Later in De grandine et tonitruis, Agobard would also recount how the prophet Elijah once prayed for a drought to afflict Israel, and the Lord withheld rain for more than three years. ${ }^{46} \mathrm{He}$ would go on to expound

\footnotetext{
43 Exodus 9:22-26.

${ }^{44}$ DGT 5, p. 6.

${ }^{45}$ DGT 5, p. 6.

${ }^{46}$ DGT 10, p. 10; from 3 Kings 17:1, although here Agobard references James 5:17-18.
} 
the power of prayer generally. Yet the tempestarii were not piously praying for the storms that they were believed to raise. Rather, they operated through "evil magic tricks." 47 The wording here was no doubt precisely intended, for Agobard does not refer to maleficium, or to incantationes as he did at the outset of his tract, but to praestigia mala, and Carolingian authorities associated praestigium with deception and demonic illusion. ${ }^{48}$ The point, therefore, is not just that the actions of the tempestarii in this instance are wicked or ungodly, but that they are ineffective, illusory, and unreal. As Agobard writes, "a sinner cannot...raise up the wind, as you tend to say, because he does not have the power, nor can he command evil angels, although in this matter they would not have power either." 49

That last point is a curious claim for Agobard to build into his argument, for other early medieval authorities absolutely believed that demons had power over the air, or at least that they could receive such power from God. Indeed, from at least the late ninth or early tenth centuries, rites for consecrating church bells regularly referred to their power to dispel storms by terrifying and driving away the demons that caused these aerial disturbances. ${ }^{50}$ Agobard, too, admits that demons have such power, albeit very briefly. After his discussion of hail in Exodus, he references Psalm 77, which ruminated on the Egyptian plagues, writing that "the Psalmist, too, who recalled this hail, says about God: He destroyed their vineyards with hail and their mulberry trees with hoarfrost. And he gave up their cattle to the hail and their possessions to the fire." But Agobard does not stop there. Instead, he writes how, "seeing that the Psalmist adds there 'sent by evil angels,' it is clear that God may employ the scourge of punishment or trial through evil ministers." 51 Moreover, he states almost immediately

${ }^{47}$ DGT 11, p. 11.

48 See, for example, the condemnation of various kinds of magical practices at the 829 Council of Paris: Albert Werminghoff, ed., Concilia aevi Karolini, Monumenta Germaniae Historica Concilia 2.2 (Hanover: Hahn, 1908), 669; Filotas, Pagan Survivals, 221, 312.

${ }^{49}$ DGT 11, p. 11.

50 John H. Arnold and Caroline Goodson, "Resounding Community: The History and Meaning of Medieval Church Bells," Viator 43 (2011): 99-130, at 118-19.

${ }^{51}$ DGT 5, p. 6. More than a decade later, Agobard returned to this same passage from Psalms in order to emphasize the power of demons as agents of divine wrath: "For blows against the impious and unfaithful are inflicted by evil angels, which the Psalmist, speaking of the plagues which struck Egypt, explicitly states, saying: He sent upon them 
thereafter that storm-raising "is certainly not in the power of human beings, either good or evil, nor is it in the power of opposing forces, but of God alone, who grants power to their evil will insofar as he wishes." 52 To argue that demonic magic could only be effective if allowed by God did not necessarily undercut the real effectiveness of that magic. Indeed, the idea that demonic magic only functioned through God's ultimate permission was axiomatic in most church authorities' treatment of magical arts in the early medieval period, ${ }^{53}$ and it would continue to be through later Christian demonology as well.

Neither did Agobard seek to deny real power to human magicians in all circumstances. When beginning his account of Moses and Aaron's confrontation with Pharaoh in Exodus, he also introduced Jannes and Jambres, "the spell-casters [incantatores] of the Egyptians, who are described as magicians [magi]," and who clearly had real power, at least up to a point. ${ }^{54}$ When Aaron threw down his rod before Pharaoh and it transformed into a serpent, they matched this feat, although Aaron's serpent devoured theirs. They also matched Moses and Aaron fully during the first plague, turning the waters of Egypt red with blood. Again during the second plague they were able to call forth frogs from the rivers, just as Moses and Aaron had, although as Agobard stresses, "they were not able to send them back [into the rivers], as Moses did through the word of the Lord." Only during the third plague would their power fail completely: "But when it came to gnats, and they were not able to do anything, they said that the finger of God was against them, and they attempted nothing more." 55

Clearly, Agobard did not think that acknowledging the reality of Jannes and Jambres' power, in certain circumstances, was detrimental to his overall argument. In fact, he turned it to his advantage, asserting that "surely if any man could cast hail, Jannes and Jambres would have cast it, because they turned water into blood, and they produced frogs from the rivers, which they who now are called tempestarii cannot do." 56

the wrath of his indignation; indignation, and wrath, and tribulation sent by evil angels." Agobard, De quorundam inlusione signorum 8, in Opera omnia, p. 241.

52 DGT 5, p. 6.

53 Benedikt Marxreiter, Bern von Reichenau, De nigromantia seu divinatione daemonum contemnenda: Edition und Untersuchung (Wiesbaden: Harrassowitz, 2016), 153-56.

54 The pair remains unnamed in Exodus but are so called in 2 Timothy 3:8.

${ }^{5}$ DGT 4, p. 5.

${ }^{56}$ DGT 4, pp. 5-6. 
The two magicians disappear from Exodus after the third plague, except for a brief mention during the sixth plague that "neither could the sorcerers [malefici] stand before Moses because of the boils that were upon them." 57 They are not mentioned at all in regard to the plague of hail, and Agobard clearly wants to infer from their absence that they were incapable of conjuring hail themselves. Strictly speaking, however, Exodus never describes Jannes and Jambres reaching some inherent limit to their power, only that their magic failed when the Lord opposed it, when "the finger of God was against them."

A similar kind of complication troubles Agobard's arguments drawn from the Book of Job, which he cites in two different sections of De grandine et tonitruis. 58 The first focuses narrowly on one passage from Job 37, which describes God manipulating the weather and particularly describes the clouds going "wherever the will of God governing them shall lead."59 "How else can this be understood," Agobard asserts, except that God alone controls the weather. He concludes again that no human beings can wield such power, other than the saints, who receive their power from God. ${ }^{60}$

A central message of the Book of Job, however, is that God acts in inscrutable ways. He does not always grant power to saints, nor does he always reward the just. Instead, he gives Satan power to afflict Job, and Agobard himself, in a later work in which he was concerned to show that not all apparently wondrous events stemmed directly from God, wrote concerning Job's afflictions that "no one doubts that this was done by the ministry of Satan." 61 Throughout later medieval demonology, as well, the Book of Job would be one of the favorite scriptural sources cited to prove the reality of demonic power in the world. For example, more than half a millennium after Agobard, the early fifteenth-century Dominican demonologist Johannes Nider would rely on the example of Job to demonstrate precisely the point that "demons and their disciples can [really] perform such witchcraft by

57 Exodus 9:11.

58 DGT 9, pp. 9-10; 13-14, pp. 12-13.

${ }^{59} \mathrm{Job} 37: 12$.

${ }^{60}$ DGT 9, p. 10.

${ }^{61}$ Agobard, De quorundam inlusione signorum 6, p. 240. 
means of lightning, hailstorms, and the like...which some doubt." 62 By that time, the capacity of demons to control the weather was firmly established in scholastic theology, and Nider was also able to draw on the authority of Thomas Aquinas to prove that "demons can cause a disturbance in the air, rouse the winds, and make fire fall from the sky" because these occurrences are ultimately generated through the movement of vapors in the atmosphere, and dominion over such things falls within the "natural power of a demon." 63

Centuries earlier, Augustine of Hippo had already established the notion of power being granted to demons in order to test the faithful and allow them to show their valor through their endurance of sufferings. ${ }^{64}$ Although he never cited Augustine, Agobard could not entirely escape the implications so apparent in the story of Job's afflictions. In his second discussion of the Book of Job, Agobard puts it thus: "He [God] granted him [Satan] power first over all his possessions, then over his children, then over the health of his body, thereafter to persuade his wife, and finally in the reproach and manifold disdain of his servants." Ultimately, all this demonic action fulfills God's will. Job is tested and humbled, but in the end "the devil withdrew conquered and confused, [and] the servant of God emerged the victor and triumphant." ${ }^{5}$ Still, that happy ending does not change the fact that, under the overarching blanket of God's majesty, the devil could wield considerable power in the world. We have already seen how, in response to the Psalms, Agobard acknowledged that God might grant power over storms to demons, in order to use them as instruments of divine wrath. Likewise, he admitted that even the tempestarii might, under certain circumstances, act as "servants of God," although never "through voluntary servitude." 66

It is important to remember, at this juncture, that Agobard was not constructing an argument about the limited or constrained nature of the tempestarii's power. He was asserting that they could never, under any

\footnotetext{
${ }^{62}$ Nider, Formicarius 5.4, in L'imaginaire du sabbat: Edition critique des texts les plus anciens (1430 c.-1440 c.), ed. Martine Ostorero, Agostino Paravicini Bagliani, and Kathrin Utz Tremp, with Catherine Chène, Cahiers Lausannoise d'Histoire Médiévale 26 (Lausanne: Université de Lausanne, 1999), 170-72.

63 Ostorero et al., ed., Imaginaire, 172; from Aquinas, Expositio super Iob ad litteram 1.3.

${ }^{64}$ Augustine, De civitate dei 10.21 .

${ }^{65}$ DGT 13, p. 12.

${ }^{66}$ DGT 5, p. 6.
} 
circumstances, do what people believed they did. Yet some of his scriptural citations could be read as calling that extreme position into doubt. Agobard moved quickly past such possibilities because, I would suggest, his own disbelief arose from a different source, visible in other aspects of his argumentation in De grandine et tonitruis. In the course of developing this tract, he turned to scriptural citations to augment the authority of his disbelief, but they are not its real root. Let me now turn to his other line of argumentation, which takes the form of brief empirical asides interspersed throughout his scriptural analysis, and examine how it functions.

\section{Agobard's experience with weather magic}

Agobard's most direct encounter with the world of the tempestarii occurred when, so he claims, he came upon a sizeable crowd, either in Lyon itself or in the vicinity. They were gathered around four people who had been placed in chains and who appeared to Agobard to have been detained thus for several days. The crowd believed that these people were aerial sailors from Magonia who had fallen out of their ship. Those who had initially captured them were now apparently whipping up the crowd into a furor in order to kill the prisoners, for Agobard describes them as looking "just like those going to be stoned." At this crucial point, however, the archbishop intervened and somehow managed to convince the crowd of its error. Unfortunately, he does not relate exactly how he did this, stating only that "the truth won out. After much argument, those who displayed them [the prisoners] were confounded, just as, according to the prophet, the thief is confounded when he is apprehended." 67 Of course, this encounter may have been entirely invented, but if it or something like it really happened, it may represent the kernel from which the rest of Agobard's disbelief in the tempestarii grew. ${ }^{68}$

The incident with the prisoners appears near the beginning of Agobard's tract. Somewhat later, after he had begun to develop his scriptural analysis, he would pause briefly in that line of argumentation to wonder why, if the tempestarii could really control the weather as people claimed, they would limit themselves to destroying crops. If they

${ }^{67}$ DGT 2, p. 4. The final reference is to Jeremiah 2:26.

${ }^{68}$ Meens, "Thunder Over Lyon," 160. 
truly wanted to harm their neighbors, why not just kill them by dumping great piles of hail on them directly, rather than on their fields? This should have been within their power, for "some say that they themselves know such tempestarii as can cause scattered hail falling widely across a region to come down in one place in a river or barren woods, or, so they say, on a tub under which he himself [the tempestarius] is hiding." 69 Agobard also notes at this point that, if the tempestarii could really conjure destructive hail, surely they could also make it rain. ${ }^{70}$ Then in a later aside he wonders why farmers do not seek out these magicians in times of drought, to save their fields rather than to destroy them. ${ }^{71}$ Since the tempestarii were thought to receive payment from the Magonians to create storms and ruin crops, it would only make sense that they would be willing to perform other meteorological services for a fee.

Agobard's ultimate empirical argument, however, is not that the tempestarii fail to act in various ways that would make sense, if they indeed wielded the sort of power that people claimed for them. It is instead that no one has actually witnessed them performing any kind of operation whatsoever. Here he relates a bit of his own sleuthing. Having heard of someone who claimed to have seen the tempestarii performing their rites, he "went through great effort" to track the man down. He then implored and even "bound him with the threat of divine punishment" to tell only the truth. At this, the man retreated slightly from his claims, stating that he knew a certain tempestarius, whom he named, and a particular time and place at which that man had supposedly conjured storms, "but he confessed that he himself had not been present at that time." 72 This absence of eyewitness testimony seems to have played a major role in convincing Agobard of the inherent falsity of all claims about the tempestarii, or at least he presents it as very damning evidence against their claims to real power.

Yet Agobard was also willing to discount testamentary evidence when it challenged his own empirical observations or reasoned conclusions. At the very end of De grandine et tonitruis he presents another incident of harmful magic, widely accepted at the time, which

\footnotetext{
${ }^{69}$ DGT 7, pp. 7-8.

${ }^{70}$ DGT 7, p. 7.

${ }^{71}$ DGT 13, p. 12.

${ }^{72}$ DGT 7, p. 8.
} 
he nevertheless categorically denies had ever taken place. Although it has nothing to do with weather magic, he frames it as a suitable conclusion to his argument about the tempestarii because it is "similar to this about which we speak." 73 Indeed, the incident in question shares much in common, at least as Agobard presents it, with his account of the tempestarii. Once again certain people claim to have committed an act of harmful, destructive magic that Agobard insists could not be real. Here he attacks not only the possibility of the malefic magic in question, in this case poisoning, but even more he focuses on what he sees as the preposterous scale of the act and the impossible logistics that it would have entailed.

The incident to which I am referring is this: a few years before Agobard sat down to write De grandine et tonitruis, in 810, an extensive murrain had struck the Carolingian world. ${ }^{74}$ There was no denying the terrible reality of this epidemic. What remained was to explain how it came about. Rumor spread that Grimoald IV, the ruler of Benevento and an enemy of the emperor Charlemagne, had dispatched agents throughout Frankish lands to scatter a poisonous powder that killed cattle. Many of his supposed agents were arrested, and moreover many of them confessed to having acted as poisoners, a fact which Agobard found truly "remarkable." We know from his report that torture was employed, and for modern sensibilities that alone might explain a false confession. The archbishop of Lyon, however, advanced a different explanation, "for the devil, having received power over them by the hidden and just judgment of God, was able to enter into them, so that they gave false testimony against themselves, even unto death."75

Like the claims of the tempestarii, these reports of enemy agents dispersing poisonous powders were "believed by everyone" and "there were very few to whom it seemed absurd." Agobard, of course, was among those who did find it absurd, but unlike with the tempestarii, here he did not mount his own investigation or seek any evidence either to confirm or to counter the confessions of the convicted poisoners. Instead he simply pointed to what he regarded as the ridiculous nature of their claims. "They did not consider rationally how such powder

\footnotetext{
${ }^{73}$ DGT 16, p. 15.

${ }^{74}$ Timothy Newfield, "A Great Carolingian Panzootic: The Probable Extent, Diagnosis and Impact of an Early Ninth-Century Cattle Pestilence," Argos 46 (2012): 200-210.

${ }^{75}$ DGT 16, pp. $14-15$.
} 
could be made, by which only cattle would be killed, not other animals, or how such powder could be carried over such very broad regions." Not if every man, woman, and child in Benevento had gone forth with cartloads of such powder, he asserted, could such widespread poisoning possibly have been accomplished. ${ }^{76}$

\section{The source of Agobard's skepticism}

The kind of conjectural, almost gut-level reaction to what he regarded as outlandish claims evident in Agobard's dismissal of the rumored mass-poisoning of cattle seems to be the real root of his opposition to belief in the tempestarii and their weather magic as well. Although he ultimately wrote a tract that argued mainly from scripture, it was not biblical analysis that instilled in him his absolute disbelief in their power. Indeed, certain parts of scripture could have called the level of his disbelief into doubt, but the good bishop either bent them to his rhetorical purpose when he could, or simply pushed past them in his analysis. Instead, he appears to have responded first and most directly to some of the more peculiar claims about the tempestarii that, he says, were being made around Lyon, and which he regarded as especially ludicrous. If they could be so accurate in their conjurations as to hit an overturned tub, why then did they not assassinate individual people who irked them through highly directed bursts of hail? If they received payment from the aerial sailors of Magonia to destroy crops, then why not try to generate some kind of income from the many farmers who would no doubt willingly pay them for rain in times of drought?

We can only speculate about what arguments Agobard may have used to convince an angry crowd to release the group of supposed Magonians that it had captured, but it seems likely that he regarded the whole notion of sky-ships and aerial sailors as utter nonsense as well. There is essentially no reference to Magonia in early medieval texts outside of De grandine et tonitruis, ${ }^{77}$ presumably indicating that, while belief in tempestarii was widespread across the Carolingian world, this particular appendage to that belief structure was quite localized around

${ }^{76}$ DGT 16, p. 15.

77 Heidecker, "Agobard en de onweermakers," 179; Jean-Claude Schmitt, "Les 'superstitions," in Histoire de la France religieuse, ed. Jacques Le Goff and René Rémond, vol. 1, Des dieux de la Gaule à la papauté d'Avignon, ed. Jacques Le Goff (Paris: Seuil, 1988), 417-555, at 465. 
Lyon. If so, then the sophisticated and worldly archbishop would have had all the more reason to find it highly risible. In fact, one expert has even speculated that Magonia might be Agobard's "own satirical coinage." 78 Another scholar has suggested a broader connection; namely, that the term might be related to maones or mavones, which in at least a couple of other eighth- and ninth-century texts designated spirits (manes) that stole crops from the fields. ${ }^{79}$ Yet there is nothing in those beliefs to suggest the notion of aerial ships carrying real, physical people who could be bound in chains - an idea that itself had at least some life outside of Agobard's description, but was not otherwise connected to weather magic in any way. ${ }^{80}$

Of course, we might also assume that Agobard invented not only the term Magonia but also the underlying beliefs that he claimed the term entailed, at least in the context of Lyon. The story of his encounter with the mob might have been a self-serving fiction as well. I find it unlikely, however, that the archbishop would have fabricated such details from whole cloth, especially in a text that probably began as a sermon preached to local audiences. This line of analysis puts me, therefore, in the camp of those who see Agobard as an at least somewhat reliable observer, and reasonably honest reporter, of common magical beliefs actually present in and around Lyon in the early ninth century. ${ }^{81}$ It also leads to a conclusion applicable to

78 Dutton, “Thunder and Hail," 174.

${ }^{79}$ Filotas, Pagan Survivals, 80-81, 273. Or possibly magonia was related to mangones, a term used in Carolingian legal texts to designate entirely mundane peddlers, swindlers, or thieves: ibid., 220, 273-74

${ }^{80}$ In the early thirteenth century, Gervase of Tilbury recorded an event "from our time" (temporibus nostris) in which an anchor from such a ship became lodged against a tombstone just outside a church. As the parishioners gathered around, a sailor climbed down to free it but was seized by the crowd and suffocated in the thick air closer to the earth, just as a human being would suffocate under water. References to such air ships are found in Celtic legends recorded at least as early as 748. See Gervase of Tilbury, Otia imperialia: Recreation for an Emperor, ed. and trans. S. E. Banks and J. W. Burns (Oxford: Clarendon Press, 2002), 80-81. I thank Joel Lipson of Cambridge University for this reference. I am also grateful to Gabriella Baika of the Florida Institute of Technology, who is studying the cultural meaning of Magonia from Agobard's time to the present, and who has generously shared some of her findings with me.

81 Heidecker, "Agobard en de onweermakers," 172; Jolivet, "Agobard de Lyon," 15. More generally see Filotas, Pagan Survivals, 46-48; Rob Meens, "Magic and the Early Medieval World View," in The Community, the Family, and the Saint: Patterns of Power in Early Medieval Europe, ed. Joyce Hill and Mary Swan (Turnhout: Brepols, 1998), 285-95. 
educated clerical authorities throughout the Middle Ages; namely, that they were often skeptical not so much about the possibility of magic per se as about the claims made by ordinary, uneducated laypeople regarding magical practices. My goal, however, has not been to discover some startlingly new mode of skepticism operating uniquely in Lyon in the early ninth century, but rather to examine carefully how different forms of doubt grounded in experience, authority (scripture), and rational conjecture could intertwine to produce one particularly powerful expression of disbelief.

Although experts are fully aware that certain kinds of magic generated considerable doubt and disbelief throughout the Middle Ages, they rarely approach the topic of magic directly from this angle. The utility of examining magic in terms of doubt, uncertainty, and outright disbelief has, so far, been more evident in studies focused on the modern period, where these are often seen as the default positions that most people would, or should, take. What those studies have increasingly shown, however, is that doubt or disbelief are never simply antithetical to continued belief in magic; rather, they are an essential part of magic's inherently uncertain nature. ${ }^{82}$ Recently Claire Fanger has argued that such "ambiguity" should be central to our understanding of medieval magic as well. ${ }^{83}$ This essay has sought to take a step in that direction. The better we understand the particular nature of medieval disbelief(s) in magic, the better we will understand the relationship between magic and other varieties of unbelief, both in the Middle Ages and beyond. We will also better understand how belief and disbelief interacted in varying ways to help form the larger patterns of continually fluctuating disenchantment and re-enchantment that characterize the history of magic as a whole.

\footnotetext{
82 In addition to studies focused on the modern West, as in n. 11 above, see also James Siegel, Naming the Witch (Stanford, Calif.: Stanford University Press, 2006); Peter Geschiere, Witchcraft, Intimacy, and Trust: Africa in Comparison (Chicago: University of Chicago Press, 2013); Nils Bubandt, The Empty Seashell: Witchcraft and Doubt on an Indonesian Island (Ithaca, N.Y.: Cornell University Press, 2014).

${ }^{83}$ Fanger, "For Magic," esp. 32-33.
} 


\section{References}

Aker. Corpus Christianorum Continuatio Mediaevalis 52. Turnhout: Brepols, 1981.

Andrews, Frances, Charlotte Metheun, and Andrew Spicer, ed. Doubting Christianity: The Church and Doubt. Studies in Church History 52. Cambridge: Cambridge University Press, 2016.

Arnold, John H. Belief und Unbelief in Medieval Europe. London: Hodder Arnold, 2005.

Arnold, John H., and Caroline Goodson. "Resounding Community: The History and Meaning of Medieval Church Bells." Viator 43 (2011): 99-130.

Bailey, Michael D. Bailey. "Diabolic Magic." In The Cambridge History of Magic and Witchcraft in the West: From Antiquity to the Present, ed. David J. Collins, 361-92. Cambridge: Cambridge University Press, 2015.

—. "The Disenchantment of Magic: Spells, Charms, and Superstition in Early European Witchcraft Literature." American Historical Review 111 (2006): 383-404.

- - Fearful Spirits, Reasoned Follies: The Boundaries of Superstition in Late Medieval Europe. Ithaca, N.Y.: Cornell University Press, 2013.

Blöcker, Monica. "Wetterzauber: Zu einem Glaubenskomplex des frühen Mittelalters." Francia 9 (1981): 117-31.

Boretius, Alfred, ed. Capitularia regnum Francorum. Monumenta Germaniae Historica Leges 2. Hanover: Hahn, 1883.

Boshof, Egon. Eræzischof Agobard von Lyon: Leben und Werk. Cologne: Böhlau, 1969.

Boureau, Alain. Satan the Heretic: The Birth of Demonology in the Medieval West. Translated by Teresa Lavender Fagan. Chicago: University of Chicago Press, 2006.

Burchard of Worms. Decretorum libri viginti. Patrologia Latina 140, col. 537-1058. Paris, 1880.

Cabaniss, Allen. Agobard of Lyons: Churchman and Critic. Syracuse, N.Y.: Syracuse University Press, 1953.

Collins, David J. "Scholasticism and High Medieval Opposition to Magic." In The Routledge History of Medieval Magic, ed. Sophie Page and Catherine Rider, 461-74. London: Routledge, 2019.

D'Avray, David L. "The Concept of Magic." In The Routledge History of Medieval Magic, ed. Sophie Page and Catherine Rider, 48-56. London: Routledge, 2019. 
Denery II, Dallas G., Kantik Gosh, and Nicolette Zeeman, ed. Uncertain Knowledge: Scepticism, Relativism, and Doubt in the Middle Ages. Turnhout: Brepols, 2014.

Dinzelbacher, Peter. Unglaube im "Zeitalter des Glaubens": Atheismus und Skeptizismus im Mittelalter. Badenweiler: Bachmann, 2009.

Duni, Matteo. "Doubting Witchcraft: Theology, Jurists, Inquisitors during the Fifteenth and Sixteenth Centuries." In Doubting Christianity: The Church and Doubt, ed. Frances Andrews, Charlotte Metheun, and Andrew Spicer, 203-31. Cambridge: Cambridge University Press, 2016.

Dutton, Paul Edward, ed. Carolingian Civilization: $A$ Reader, 2nd ed. Peterborough, Ont.: Broadview Press, 2004.

- _. "Thunder and Hail over the Carolingian Countryside." In Dutton, Charlemagne's Mustache and Other Cultural Clusters of a Dark Age, 16988. New York: Palgrave Macmillan, 2004.

Fanger, Claire. "For Magic: Against Method." In The Routledge History of Medieval Magic, ed. Sophie Page and Catherine Rider, 26-36. London: Routledge, 2019.

Filotas, Bernadette. Pagan Survivals, Superstitions and Popular Cultures in Early Medieval Pastoral Literature. Toronto: University of Toronto Press, 2005.

Flanagan, Sabina. Doubt in an Age of Faith: Uncertainty in the Long Twelfth Century. Turnhout: Brepols, 2008.

Flint, Valerie I. J. The Rise of Magic in Early Medieval Europe. Princeton, N.J.: Princeton University Press, 1991.

Heidecker, Karl. "Agobard en de onweermakers: Magie en rationaliteit in de vroege Middeleeuwen." In De betovering van het middeleeunse Christendom: Studies over ritueel en magie in de Middeleeunen, ed. M. Mostert and A. Demyttenaere, 171-94. Hilversum: Verloren, 1995.

Jolivet, Jean. "Agobard de Lyon et les faiseurs de pluie." In La méthode critique au Moyen Âge, ed. Mireille Chazan and Gilbert Dahan, 15-25. Turnhout: Brepols, 2006.

Kieckhefer, Richard. Magic in the Middle Ages. Cambridge: Cambridge University Press, 1989.

—_. "Rethinking How to Define Magic." In The Routledge History of Medieval Magic, ed. Sophie Page and Catherine Rider, 15-25. London: Routledge, 2019. 
- - "The Specific Rationality of Medieval Magic." American Historical Review 99 (1994): 813-36.

Marxreiter, Benedikt. Bern von Reichenau, De nigromantia seu divinatione daemonum contemnenda: Edition und Untersuchung. Wiesbaden: Harrassowitz, 2016.

McNeill, John T., and Helena M. Gamer, eds. Medieval Handbooks of Penance: A Translation of the Principal Libri Poenitentiales. New York: Columbia University Press, 1938.

Meens, Rob. "Magic and the Early Medieval World View." In The Community, the Family, and the Saint: Patterns of Power in Early Medieval Europe, ed. Joyce Hill and Mary Swan, 285-95. Turnhout: Brepols, 1998.

—_. "Thunder Over Lyon: Agobard, the tempestarii and Christianity." In Paganism in the Middle Ages: Threat and Fascination, ed. Carlos Steel, John Marenbon, and Werner Verbeke, 157-66. Leuven: Leuven University Press, 2012.

Nelson, Jinty. "Carolingian Doubt?" In Doubting Christianity: The Church and Doubt, ed. Frances Andrews, Charlotte Metheun, and Andrew Spicer, 65-86. Cambridge: Cambridge University Press, 2016.

Newfield, Timothy. "A Great Carolingian Panzootic: The Probable Extent, Diagnosis and Impact of an Early Ninth-Century Cattle Pestilence." Argos 46 (2012): 200-210.

Ostorero, Martine. Le diable au sabbat: Littérature démonologique et sorcellerie (1440-1460). Micrologus' Library 38. Florence: SISMEL, 2011.

Ostorero, Martine, Agostino Paravicini Bagliani, and Kathrin Utz Tremp, with Catherine Chène, ed. L'imaginaire du sabbat: Edition critique des texts les plus anciens (1430 c.-1440 c.). Cahiers Lausannoise d'Histoire Médiévale 26. Lausanne: Université de Lausanne, 1999.

Otto, Bernd-Christian. "A Discourse Historical Approach towards Medieval Learned Magic." In The Routledge History of Medieval Magic, ed. Sophie Page and Catherine Rider, 37-47. London: Routledge, 2019.

Pelkmans, Mathijs. "Outline for an Ethnography of Doubt." In Ethnographies of Doubt: Faith and Uncertainty in Contemporary Societies, ed. Mathijs Pelkmans, 1-42. London: I. B. Taurus, 2013.

Reynolds, Susan. "Social Mentalities and the Cases of Medieval Scepticism." Transactions of the Royal Historical Society, 6th ser. 1 (1991): 21-41. 
Schmitt, Jean-Claude. "Les 'superstitions."” In Histoire de la France religieuse, ed. Jacques Le Goff and René Rémond, 1:417-555. Paris: Seuil, 1988.

Scribner, R. W. "Magic and the Formation of Protestant Popular Culture in Germany." In R. W. Scribner, Religion and Culture in Germany (1400-1800), ed. Lyndal Roper, Studies in Medieval and Reformation Thought 81, 323-458. Leiden: Brill, 2001.

- . "The Reformation, Popular Magic, and the 'Disenchantment of the World." Journal of Interdisciplinary History 23 (1992-93): 475-94.

Shagan, Ethan S. The Birth of Modern Belief: Faith and Judgment from the Middle Ages to the Enlightenment. Princeton, N.J.: Princeton University Press, 2018.

Steinruck, Josef. "Zauberei, Hexen- und Dämonenglaube im Sendhandbuch des Regino von Prüm." In Hexenglaube und Hexenprozesse im Raum Rhein-Mosel-Saar, ed. Gunther Franz and Franz Irsigler, 3-18. Trier: Spee, 1995.

Stephens, Walter. Demon Lovers: Witchcraft, Sex, and the Crisis of Belief. Chicago: University of Chicago Press, 2002.

- . "The Sceptical Tradition." In The Oxford Handbook of Witchcraft in Early Modern Europe and Colonial America, ed. Brian P. Levack, 10121. Oxford: Oxford University Press, 2013.

Thomas, Keith. Religion and the Decline of Magic. New York: Scribner's, 1971.

Tschacher, Werner. "Der Flug durch die Luft zwischen Illusionstheorie und Realitätsbeweis: Studien zum sog. Kanon Episcopi und zum Hexenflug." Zeitschrift der Savigny-Stiftung für Rechtsgeschichte 116, Kanonistische Abteilung 85 (1999): 225-76.

Walsham, Alexandra. "The Reformation and 'The Disenchantment of the World' Reassessed.” The Historical Journal 51 (2008): 497-528.

Weltecke, Dorothea. "Beyond Religion: On the Lack of Belief during the Central and Later Middle Ages." In Religion and Its Other: Secular and Sacral Concepts and Practices in Interaction, ed. Heike Bock, Jörg Fuechter, and Michi Knecht, 101-14. Frankfurt: Campus Verlag, 2009.

-. "Der Narr spricht: Es ist kein Got": Atheismus, Unglauben und Glaubenszweifel vom 12. Jahrbundert bis zur Neuzeit. Frankfurt: Campus Verlag, 2010. 
Werminghoff, Albert, ed. Concilia aevi Karolini. Monumenta Germaniae Historica Concilia 2.2. Hanover: Hahn, 1908.

Whitmarsh, Tim. Battling the Gods: Atheism in the Ancient World. New York: Knopf, 2015. 